\title{
KENAKALAN ANAK (JUVENILE DELIQUENCY): KAUSALITAS DAN UPAYA PENANGGULANGANNYA
}

\author{
Sarwirini \\ Fakultas Hukum Universitas Airlangga Surabaya \\ e-mail: sarwirini.rini@fh.unair.ac.id
}

\begin{abstract}
ABSTRAK
Akhir-akhir ini kenakalan anak telah membawa kepada perilaku kejahatan sebagai akibat kasus anak-anak bermasalah dengan hukum. Usaha untuk mengatasi masalah kenakalan anak dilakukan melalui pelanggaran kepolisian maupun tidak. Akan tetapi beberapa pendekatan untuk mencegah dan mengatasi kenakalan anak yang terjadi saat ini memiliki tendensi untuk melakukan pendekatan yang represif. Terlebih lagi memenjarakan anak-anak yang bermasalah dengan hukum masih sangat menonjol. Pendekatan dan metode yang tepat untuk mengatasi masalah kenakalan anak harus dilakukan dan didasarkan pada pemahaman yang komprehensif dari sebab-sebabnya. Jadi artikel ini bertujuan untuk membahas sebab-sebab kenakalan anak baik dari perspektif teori maupun konsepnya dan juga lingkup hukum serta metode untuk mengatasi kenakalan anak di Indonesia.
\end{abstract}

Kata Kunci: kenakalan anak, upaya menanggulanginya.

\begin{abstract}
Currently juvenile deliquency has leaded into criminal behaviour as the result the case of children in conflict with the law arises. The efforts to overcome the matters of juvenile deliquency is performed through penal policy and non penal policy. However, such approaches to prevent and to overcome juvenile deliquency that exist today, have a tendency to perform repressive approach. Moreover, imprisonment to children in conflict with the law is still a very prominent way. The appropriate methode and approach to overcome the matters of juvenile deliquency should be performed and based on deep understanding on the causes of juvenile deliquency. Thus, this article aims to discuss the causes of juvenie deliquency both from the perspective of theories and concepts within juvenile deliquency. Besides that it discuss the legal framework and the methode to overcoming the juvenile deliquency in Indonesia.
\end{abstract}

Keywords: juvenile deliquency, effort to overcome it.

\section{PENDAHULUAN}

Pada umumnya perilaku kenakalan anak dan remaja dimaknai sebagai suatu bentuk perilaku yang tidak sesuai dengan norma-norma yang hidup di tengah masyarakat. Perilaku anak yang tidak sesuai dengan norma itu dianggap sebagai anak yang cacat sosial (Kartini Kartono, 1988:93) dan kemudian masyarakat menilai cacat tersebut sebagai sebuah kelainan sehingga perilaku mereka pun disebut dengan kenakalan.

Pengertian kenakalan anak atau juvenile delinquency yang dikemukakan oleh para ilmuwan beragam. Namun pada intinya menyepakati bahwa kenakalan anak merupakan perbuatan atau tingkah laku yang bersifat anti sosial. Sebagaimana juga disepakati oleh badan peradilan Amerika Serikat pada saat pembahasan Undang-Undang Peradilan Anak di negara tersebut (Wagiati Soetodjo, 2008:9).
Menurut bentuknya, Sunarwiyati S. (1985), membagi kenakalan anak dan remaja ke dalam tiga tingkatan; a. kenakalan biasa, seperti suka berkelahi, suka keluyuran, membolos sekolah, pergi dari rumah tanpa pamit, b. kenakalan yang menjurus pada pelanggaran dan kejahatan seperti mengendarai mobil tanpa SIM, mengambil barang orangtua tanpa izin, c. kenakalan khusus seperti penyalahgunaan narkotika, hubungan seks di luar nikah, pemerkosaan dan lainlain. Sedangkan dari sisi hukum, berdasarkan Pasal 1 Butir 2 Undang-Undang Nomor 3 Tahun 1997 tentang Pengadilan Anak, mengkualifikasikan kenakalan anak (anak nakal) sebagai anak yang melakukan tindak pidana dan anak yang melakukan perbuatan yang terlarang bagi anak, baik menurut peraturan perundang-undangan maupun menurut peraturan hukum lain yang hidup dan berlaku dalam masyarakat yang bersangkutan. 
Tindakan atau perbuatan pelanggaran norma, baik norma hukum maupun norma sosial, yang dilakukan oleh anak di usia muda, memang tidak dikatakan sebagai sebuah kejahatan anak, karena penyebutan kejahatan anak akan terlalu ekstrim bagi seorang anak yang melakukan tindak pidana dikatakan sebagai penjahat. Sementara kejadiannya adalah proses alami yang tidak boleh tidak setiap manusia pernah mengalami fase kegoncangan semasa menjelang kedewasaannya (Wagiati Soetodjo, 2008:12).

Saat ini kenakalan anak telah banyak yang menjurus pada pelanggaran dan kejahatan sehingga jumlah anak yang berhadapan dengan hukum selalu meningkat (Ditjen Lapas Depkumham, 2008). Dari fenomena tersebut muncul reaksi masyarakat untuk menanggulanginya yang kemudian diwujudkan dalam bentuk kebijakan kriminal.

Kebijakan kriminal sebagai bentuk reaksi masyarakat terhadap permasalahan penanggulangan kenakalan anak dilakukan melalui sarana penal dan non penal. Upaya penanggulangan dengan pendekatan-pendekatan yang ada saat ini memang memiliki kecenderungan untuk lebih mengutamakan sarana pendekatan represif serta penjatuhan sanksi-sanksi pidana berupa pemenjaraan masih sangat mengemuka, meskipun implikasinya dapat berpengaruh buruk pada masa pertumbuhan dan perkembangan psikis dan fisik seorang anak. Bahkan implikasi tersebut dapat berakibat trauma yang dapat berpengaruh pada kehidupan di masa dewasanya.

Upaya penanggulangan kenakalan anak sudah semestinya dimulai dari pengetahuan yang cukup mengenai latar belakang dan sebab musabab perilaku kenakalan tersebut. Untuk itu perlu dirumuskan dan digunakan metode serta pendekatan-pendekatan yang tepat dalam upaya penanganan dan penanggulangan perilaku-perilaku kenakalan anak. Pemahaman yang salah mengenai sebab musabab (kausalitas) kenakalan anak akan menyebabkan timbulnya pemberian terapi yang salah dalam rangka menyembuhkan dan menanggulangi perilaku kenakalan anak. Artikel ini akan membahas tentang bagaimana kausalitas kenakalan anak berdasarkan teori dan konsep dalam juvenile deliquency serta bagaimana landasan hukum dan metode yang menjadi dasar penanggulangan kenakalan anak di Indonesia.

\section{PEMBAHASAN}

\section{Kausalitas Kenakalan Anak}

Pada awalnya para kriminolog mengasumsikan bahwa unsur-unsur niat dan kesempatan sangat berpengaruh terhadap sebab-sebab (kausalitas) timbulnya kejahatan atau kenakalan anak. Hasil dalam Seminar Kriminologi III di Semarang (1976) menyatakan bahwa unsur niat terkait dengan faktor-faktor endogen dan eksogen. Yang dimaksud dengan faktor endogen tersebut adalah faktor-faktor yang berasal dari dalam diri anak itu sendiri yang mempengaruhi tingkah lakunya, antara lain: a. cacat yang bersifat biologis dan psikis; b. perkembangan kepribadian dan intelegensi yang terhambat sehingga tidak bisa menghayati norma-norma yang berlaku.

Sedangkan faktor-faktor eksogen adalah faktor berasal dari luar diri anak yang dapat mempengaruhi tingkah lakunya. Sedangkan menurut Tannebaum (Giallombardo, 1972), bahwa sebagaimana kejahatan, terjadinya delinkuensi anak itu karena adanya konflik antara suatu kelompok (group) dengan masyarakat (community) yang lebih luas. Oleh karena itu, permasalahan kenakalan anak atau delinkuensi anak bukan hanya disebabkan oleh faktor biologis dan psikologis anak saja. Faktor sosial, khususnya lingkungan pergaulannya (peers group), dapat menjadi salah satu sebab utama terjadinya kenakalan tersebut.

Dalam pergaulan sehari-hari sebagai makhluk sosial, maka baik penjahat maupun anak delinkuen itu hidup di tengah-tengah masyarakat bersama-sama dengan suatu kelompok tertentu. Kalau seseorang yang normal mungkin tidak mengalami kesulitan menyesuaikan dirinya dengan kelompoknya. Namun tidak demikian kalau seseorang itu dalam kondisi atau keadaan tidak normal, ia akan mengalami kesulitan menyesuaikan dirinya dengan kelompok yang lebih besar. Dalam hal ini, Tannebaum berpendapat bahwa "most delinquencies are comitted in groups; most criminals live in, operate with, and are supported by groups". Dengan demikian kelompok dimana seseorang hidup dan melangsungkan kegiatannya dapat berpengaruh terhadap tingkah lakunya. Apalagi jika seseorang itu masih termasuk dalam kelompok anak yang masih labil kepribadiannya dan masih dalam tahap pencarian jati dirinya. Mereka inilah yang dengan mudah dapat dipengaruhi ataupun diprovokasi oleh hal-hal negatif yang menjurus pada pelanggaran, baik pelanggaran norma hukum maupun pelanggaran norma yang lain.

Edwin H. Sutherland, dalam teorinya differential association menjelaskan bahwa pengaruh perilaku kelompok pada sikap seseorang itu dengan cara berinteraksi melalui proses pembelajaran. Secara rinci 9 (sembilan) preposisi Sutherland dalam teorinya adalah sebagai berikut: pertama, "criminal behaviour is learned", dalam hal ini perilaku jahat atau kriminal 
terjadi karena dipelajari, bukan dibawa sejak lahir; kedua, perilaku kriminal tersebut dipelajari dalam interaksinya dengan orang lain dalam suatu proses komunikasi, baik melalui komunikasi verbal maupun isyarat; ketiga, bagian yang pokok dari proses belajar perilaku kriminal terjadi dalam hubungan yang intim atau hubungan pribadi yang erat dengan kelompoknya; keempat, perilaku kriminal yang dapat dipelajari itu meliputi teknik-teknik melakukan tindak kriminal (dari teknik sederhana sampai teknik yang rumit), dan juga belajar mengenai pengarahan khusus mengenai motif, nafsu, rasionalisasi, dan sikap; kelima, pengarahan khusus dari motif dan rangsangan atau dorongan dipelajari dari ketentuan-ketentuan aturan hukum yang menyenangkan atau menguntungkan atau pun tidak menyenangkan (unfavorable); keenam, seseorang menjadi delinkuen karena adanya suatu ekses (akibat atau dampak) ketentuan-ketentuan yang menyenangkan atau menguntungkan daripada ketentuan-ketentuan yang tidak menguntungkan untuk melakukan pelanggaran hukum. Inilah yang merupakan prinsip dari asosiasi deferensial, yang berlaku, baik bagi asosiasi-asosiasi kriminal maupun nonkriminal. Orang menjadi kriminal karena adanya hubungan (contact) dengan pola-pola kriminal dan karena terpisahnya dengan pola-pola anti kriminal; ketujuh, asosiasi-asosiasi diferensial itu bervariasi di dalam frekuensi, waktu, prioritas, dan intensitas; kedelapan, proses belajar perilaku kriminal melalui asosiasi dengan pola-pola kriminal dan anti kriminal mencakup mekanisme yang terjadi pada proses belajar lainnya. Artinya, proses belajar perilaku kriminal tersebut tidak terjadi semata-mata secara imitasi, tapi melalui pengamatan dan pembelajaran secara langsung. kesembilan, perilaku kriminal tidak dapat dijelaskan oleh nilai nilai dan kebutuhan-kebutuhan umum, karena perbuatan nonkriminal pun merupakan ekspresi dan nilai-nilai dan kebutuhan yang sama.

Dari teori atau konsep Sutherland tersebut dapat diasumsikan bahwa bagi anak, lingkungan pergaulan (peer group) yang jelek atau buruk cenderung dapat mendorong terbentuknya perilaku yang buruk (negatif) pula, yang bahkan dapat menjurus pada perilaku yang melanggar hukum, baik dalam taraf yang ringan (mengutil atau mencuri) sampai yang berat (menganiaya atau membunuh). Bahkan dengan maraknya kasus-kasus perkelahian antar pelajar, maka lingkungan pergaulan yang buruk merupakan tempat yang potensial bagi kausa terjadinya kenakalan anak. Kasus-kasus school bullying yang terjadi di antara pelajar, geng nero yang merupakan identifikasi kumpulan anak perempuan nakal, atau pun kasus tawuran antar sekolah merupakan beberapa contoh yang perlu dicermati dan diantisipasi oleh pihakpihak yang berwenang di Indonesia dengan upaya penanggulangan yang terkoordinasi dan terintegarsi dengan baik.

Bahkan terkait school bullying (Sarwirini, 2009), kenakalan murid yang tidak diantisipasi sejak awal dapat menimbulkan kemarahan gurunya sehingga khilaf melakukan pemukulan pada muridnya. Juga dalam suatu program pelatihan guru-guru di lingkungan Pemerintah Kota Mojokerto (2008), dan juga dalam Pengabdian Masyarakat untuk guru-guru di lingkungan Pemerintah Kabupaten Tulungagung (2009) dan Dinas Kota Surabaya (2010), terungkap bahwa Penerapan Undang-Undang Perlindungan Anak yang tidak proporsional dapat berimplikasi menjadikan murid menjadi manja dan nakal sementara para guru seringkali ragu-ragu atau takut untuk bertindak dengan tepat. Disinilah perlunya koordinasi di antara orangtua murid, dewan pengawas sekolah dan aparat penegak hukum sehingga dapat mengantisipasi dampak negatif akibat pergaulan yang tidak sehat di sekolah.

Selain konsep Sutherland, dalam perspektif lain terdapat beberapa teori yang dapat memberikan penjelasan tentang latar belakang perilaku jahat yang dilakukan oleh anak. Teori-teori tersebut diantaranya yaitu:

a. Teori Kontrol Sosial

Teori Kontrol Sosial atau sering disebut Teori Kontrol, berangkat dari asumsi dasar bahwa individu dalam masyarakat mempunyai kecenderungan yang sama kemungkinannya menjadi baik atau jahat. Baik jahatnya seseorang sepenuhnya tergantung pada masyarakatnya. Ia menjadi baik kalau masyarakatnya membuatnya demikian dan menjadi jahat apabila masyarakatnya membuat demikian (John Hagan, Modern Criminology). Pertanyaan dasar yang dilontarkan paham ini berkaitan dengan unsur-unsur pencegahan yang mampu menangkal timbulnya perilaku delinkuen (dalam hal ini perilaku jahat) di kalangan anggota masyarakat, utamanya pada anak anak, yaitu: mengapa mereka patuh dan taat pada norma-norma masyarakat? Atau mengapa mereka tidak melakukan perilaku menyimpang? Pertanyaan tersebut mencerminkan bahwa penyimpangan bukan merupakan problematik, yang dipandang sebagai persoalan pokok adalah ketaatan atau kepatuhan pada norma-norma kemasyarakatan.

Dengan demikian menurut paham ini sesuatu yang perlu dicari kejelasan tentang ketaatan seseorang pada norma dan faktor-faktor yang menyebabkan patuh atau 
taat pada norma-norma kemasyarakatan. Pada dasarnya upaya penjelasan penyimpangan perilaku tidak harus dilakukan dengan cara menjelaskan perilaku tidak patuh norma (Travis Hirschi, Berkeley, 1969). Oleh karena itu, penganut paham ini berpendapat bahwa ikatan sosial (social bond) seseorang dengan masyarakatnya dipandang sebagai faktor pencegah timbulnya penyimpangan. Seseorang yang lemah atau terputus ikatan sosialnya dengan masyarakat, dan dapat bebas melakukan penyimpangan. Selanjutnya Travis Hirschi mengklasifikasikan unsur-unsur ikatan sosial itu meliputi: a. Attachment, b. Commitment, c. Involvment, dan d. Belief.

Attachment, mengacu pada kemampuan seseorang untuk menginternalisasikan norma-norma masyarakat. Kalau seseorang melanggar norma-norma masyarakat, maka berarti ia tidak peduli dengan pandangan serta kepentingan orang lain, berarti ia tidak terikat lagi dengan norma-norma masyarakat itu. Orang-orang tersebut tidak terikat lagi dengan masyarakat, tidak peka dengan kepentingan orang lain, sehingga ia akan merasa bebas untuk melakukan penyimpangan.

Commitment, mengacu pada perhitungan untungrugi keterlibatan seseorang dalam perbuatan penyimpangan, dimana orang pada umumnya menginventarisasikan segala hal termasuk waktunya, tenaga dirinya sendiri dalam kegiatan di masyarakat, dengan maksud untuk memperoleh reputasi di masyarakat.

Involvment, mengacu pada suatu pemikiran bahwa apabila seseorang disibukkan dalam berbagai kegiatan konvensional maka ia tidak akan pernah sempat berpikir apalagi melibatkan diri dalam perbuatan penyimpangan. Seseorang yang terlibat dalam kegiatan konvensional berarti ia terikat dengan segala aspek yang terkandung dalam kegiatan tersebut.

Belief, mengacu pada situasi keanekaragaman penghayatan kaidah kemasyarakatan (terutama pada keabsahan moral) di kalangan anggota masyarakat. Para pelaku penyimpangan tersebut umumnya mengetahui bahwa perbuatannya salah, namun makna dan pemahamannya itu kalah bersaing dengan keyakinan lain (kerancuan penghayatan keabsahan moral), sehingga kendor ikatan dirinya dengan tertib masyarakat dan pada gilirannya ia merasa bebas untuk melakukan penyimpangan. Dalam kondisi dan situasi kekinian, dimana masyarakat berkembang maka keberadaan ikatan sosial sangat berpeluang untuk menjadi mengendor bahkan terlepas dari ikatan masyarakat, utamanya pada kalangan anak.

b. Teori Subkultur Delinkuen

Teori ini dapat ditemukan dalam bukunya Albert K. Cohen (1955) yang berjudul Delinkuen Boys, The
Culture of The Gang. Fokus perhatiannya terarah pada satu pemahaman bahwa perilaku delinkuen di kalangan usia muda, kelas bawah merupakan cerminan ketidakpuasan terhadap norma-norma dan nilai-nilai kelompok kelas menengah dan mendominasi kultur masyarakat. Karena kondisi sosial yang ada dipandang seabagai kendala upaya mereka untuk mencapai kehidupan sesuai dengan trend yang ada, sehingga mendorong kelompok usia muda kelas bawah mengalami konflik budaya, yang disebut status frustation. Akibatnya, meningkatkan keterlibatan anak-anak kelas bawah itu pada kegiatan geng-geng dan berperilaku menyimpang yang sifatnya "nonutilitarian, nonmaliciaous and nonnegatistics" (Albert K. Cohen, 1955:25).

Para pelaku delinkuen merupakan bentukan subbudaya terpisah dan memberlakukan sistem tata nilai masyarakat luas. Ia menggambarkan sub-budaya sesuatu yang diambil dari norma-norma budaya yang lebih besar, namun kemudian dibelokkannya secara terbalik dan berlawanan. Perilaku delinkuensi dibenarkan oleh sistem tata nilai budaya mereka, karena perilaku itu dianggap keliru oleh normanorma budaya yang lebih besar (Albert K. Cohen, 1955:26-27) membuat klasifikasi dari sub-sub budaya delinkuen menjadi:

a. a parent sub-culture - the negativistic subcultur originally identified to delinquent boys; $\mathrm{b}$. the conflict-oriented subcultur - the cultur of a large gang that engages in collective violence; c. the drug addict subcultur - groups of youth whose lives revolve around the purchase sale, use of narcotics; $\mathrm{d}$. semi professional theft - youths who engage in the theft or robbery of merchandise for the purpose of later sale and monetary gain; and e. middle class subcultur - delinquent group that rise, because of the pressures of living in middle class environment.

Lebih lanjut R.A. Cloward dan L.E. Ohlin mengemukakan teori yang disebut Differential Opportunity System. Teori ini mengemukakan bahwa penyimpangan di suatu wilayah perkotaan merupakan fungsi dari perbedaan kesempatan yang dimiliki anakanak untuk mencapai, baik tujuan yang legal maupun yang ilegal. Manakala kesempatan untuk memperoleh yang legal terblokir maka tindak kriminal pun mungkin terjadi, sehingga kecenderungan keterlibatan pada penggunaan narkotika atau dengan kekerasan juga dapat terjadi. Sub budaya yang mungkin terjadi menurut Cloward dan Ohlin dikelompokkan menjadi 3 (tiga) bentuk yaitu: 1. criminal subcultur, bentuk-bentuk perilaku geng yang ditujukan untuk kepentingan pemenuhan uang atau harta benda; 2 . conflict subcultur, bentuk geng yang berusaha mencari status dengan menggunakan kekerasan; 3 . reatreatist subcultur, bentuk geng dengan ciri-ciri penarikan diri 
dari tujuan dan peranan konvensional dan kemudian mencari pelarian dengan menyalahgunakan obat atau narkotika atau sejenisnya.

c. Teori Anomi

Teori Anomi diajukan oleh Robert K. Merton, dimana dalam teorinya mencoba melihat keterkaitan antara tahap-tahap tertentu dari struktur sosial dengan perilaku delinkuen, ia melihat bahwa tahapan tertentu dari struktur sosial akan menumbuhkan suatu kondisi dimana pelanggaran terhadap norma-norma kemasyarakatan merupakan wujud reaksi normal (jadi seolah-olah terjadi keadaan tanpa norma atau anomi).

Dalam teori anomi terdapat dua unsur yang dijadikan perhatian dalam mempelajari berbagai bentuk perilaku delinkuen yaitu unsur struktur sosial dan budaya. Unsur budaya menghasilkan goals yang berarti adanya tujuan-tujuan dari kepentingankepentingan yang sudah membudaya, yang meliputi kerangka aspirasi dasar manusia, seperti dorongan untuk hidup. Tujuan tersebut merupakan bentuk kesatuan dan didasari oleh urutan nilai dalam berbagai tingkatan perasaan dan makna.

Sedangkan unsur struktural menimbulkan adanya means yang berarti bahwa adanya aturan-aturan dan cara-cara kontrol yang melembaga dan diterima sebagai sarana untuk mencapai tujuan yang telah membudaya dalam masyarakat.

d. Teori Belajar

Teori Belajar (Social Learning Theory), dikembangkan oleh Ronald Akkers yang dikaitkan dengan delinkuensi anak. Pendekatannya berpegang pada asumsi, bahwa perilaku seseorang dipengaruhi oleh pengalaman belajar, pengalaman kemasyarakatan disertai nilai-nilai dan penghargaan dalam kehidupan di masyarakat.

Secara umum, teori ini berpandangan bahwa anakanak akan memperagakan perilakunya atas dasar: a. reaksi yang diterimanya dari pihak lain (positif atau negatif), b. perilaku orang dewasa yang mempunyai hubungan dekat dengan mereka (utamanya orangtua), dan c. perilaku yang mereka lihat di TV maupun di bioskop. Apabila seorang anak mengamati perilaku agresif, misalnya orang dewasa menampar atau memukul orang lain saat bertengkar, dan apabila anak melihat bahwa perilaku agresif diperbolehkan atau mendatangkan hadiah (pujian), akan terjadi kecenderungan anak akan bereaksi dengan cara kekerasan selama ia mengalami kejadian serupa. Akhirnya anak pun akan menguasai teknik-teknik agresifitas dan akan semakin yakin bahwa penggunaan kekerasan itu akan mendatangkan hadiah (pujian).
Dampaknya, pengikut teori ini menyatakan seorang anak yang tumbuh kembang dalam lingkungan rumah dimana kekerasan menjadin kebiasaan, maka anak pun akan belajar untuk meyakini bahwa perilaku seperti itu dapat diterima dan mendatangkan hadiah atau pujian (Paulus Hadisuprapto, 2002:78-79).

e. Teori Kesempatan

Teori kesempatan berangkat dari asumsi dasar, bahwa terdapat hubungan yang kuat antar lingkungan kehidupan anak, struktur ekonomi dan pilihan perilaku yang diperbuat selanjutnya. Richard A. Cloward dan Lloyn Ohlin berpendapat bahwa munculnya subcultur delinkuen dan betuk-bentuk perilaku yang muncul dari itu, tergantung pada kesempatan, baik kesempatan patuh norma maupun kesempatan penyimpangan norma. Apabila kelompok anak (dalam status ekonomi dan lingkungannya itu) terblokir oleh kesempatan patuh norma dalam rangka mencapai sukses hidupnya, mereka akan mengalami frustrasi (status frustation), tanggapan mereka dalam menanggapi frustasi statusnya, sangat tergantung pada terbukanya struktur kesempatan yang ada di hadapan mereka (Richard A. Cloward dan Lloyn Ohlin, 1960:9).

Secara singkat, Cloward \& Ohlin memandang delinkuensi wilayah perkotaan, merupakan fungsi dari perbedaan kesempatan kelompok anak untuk memperoleh tujuan baik yang patuh norma maupun yang menyimpang. Bilamana kesempatan patuh hukum terblokir, kecenderungan munculnya perilaku delinkuensi pun besar. Teori Cloward dan Ohlin ini, berusaha mengintegrasikan tiga aliran delinkuensi, Teori Sub-kultur (Albert K. Cohen), Teori Belajar (Ronald Akkers) dan Teori Anomi (Robert Merton) (Richard A. Cloward \& Lloyn Ohlin, 1960).

Teori-teori di atas dapat dijadikan bahan pertimbangan dalam menanggulangi kejahatan yang dilakukan oleh anak, sehingga latar belakang anak melakukan kejahatan dipahami dengan tepat, untuk diterapkan kebijakan penanggulangan dengan tepat pula. Termasuk dalam upaya penanggulangan kejahatan dengan sarana atau kebijakan non penal.

Adanya keterbatasan dan kelemahan kebijakan penal sebagai sarana penanggulangan kejahatan (bersifat symptomatik, bahkan bersifat kriminogen - melahirkan stigma sosial), mendorong perlunya dikedepankan kebijakan non-penal dalam konteks penanggulangan kejahatan di masyarakat. Dilihat dari sisi kebijakan non-penal ini berarti perlu digali, dikembangkan dan dimanfaatkan seluruh potensi dukungan dan partisipasi masyarakat dalam upaya pengefektifan dan pengembangan "extra legal system" atau "informal and tradisional system" 
yang ada di masyarakat (Barda Nawawi Arif, 1996: 57) sebagai upaya penanggulangan kejahatan yang bersifat "mencegah atau menangkal" terjadinya kejahatan, maka sasaran utama upaya "non-penal" adalah menangani faktor-faktor kondusif penyebab terjadinya kejahatan, seperti kondisi-kondisi sosial yang secara langsung dan tidak langsung dapat menimbulkan kejahatan.

\section{Upaya Penanggulangan Kenakalan Anak}

"Mencegah lebih baik daripada memperbaiki", demikian pepatah ini ditulis atau didengar. Namun dalam pelaksanaannya seringkali pula kita lengah, baru sadar kalau sesuatu kejadian atau peristiwa yang buruk tersebut sudah terjadi. Demikian pula halnya dengan masalah kenakalan anak. Misalnya, kalau disadari bahwa pergaulan (peer group) merupakan salah satu faktor dominan yang dapat menimbulkan kausalitas kenakalan anak, maka seharusnyalah upaya pencegahan itu dapat dilakukan setiap orang tua, guru, atau pun pihak yang terkait dengan mengawasi kelompok bermain anak. Tetapi tidak jarang pula anak dapat mengelabuhi atau memperdayai pihak yang memelihara atau mengawasinya, seperti dalam kasuskasus penyalahgunaan narkoba di kalangan remaja.

Upaya penanggulangan kenakalan anak memang harus benar-benar dilakukan sedini mungkin, karena berdasarkan suatu penelitian ditemukan bahwa $80 \%$ anak-anak delinkuen jika tidak ditangani secara benar akan dapat berkembang menjadi penjahat (criminal) pada masa dewasanya (A. Phelps dan Henderson, 1981) di lain pihak, kejahatan atau kenakalan anak itu sendiri sangat kompleks, oleh karena itu banyak teori atau pendekatan yang membahas permasalahan kenakalan anak. Dalam perspektif kriminologi, para ahli sering membahasnya melalui pendekatanpendekatan (approaches) biologis, psikologis, dan sosial. Dalam era modern saat ini terdapat kecenderungan bahwa faktor lingkungan dapat menjadi salah satu faktor dominan yang menyebabkan terjadinya kenakalan anak. Selain itu, dari faktor lingkungan pula dapat digunakan sebagai salah satu sarana (solusi) dalam upaya penanggulangan kenakalan anak.

Lingkungan di mana anak tumbuh dan berkembang sesungguhnya ikut bertanggungjawab dalam upaya menanggulangi kenakalan anak. Oleh karena anak adalah tunas, potensi, dan generasi muda penerus cita-cita perjuangan bangsa, memiliki peran strategis dan mempunyai ciri dan sifat khusus yang menjamin kelangsungan eksistensi bangsa dan negara pada masa depan, demikian disebutkan dalam Bab Menimbang, baik dalam Undang-Undang No. 3 Tahun 1997 tentang Pengadilan Anak maupun dalam Undang-Undang No. 23 Tahun 2002 tentang Perlindungan Anak. Kedudukan anak yang strategis, yang tersurat dalam kedua undang-undang tersebut, pada hakekatnya juga menjadi landasan bebagai konsep atau teori modern yang terkait dalam upaya penanggulangan kenakalan anak. Oleh karena itu, dalam filosofi pemidanaan pada anak yang nakal pun aspek-aspek "health" dan "wealth" menjadi dua aspek penting yang perlu diperhatikan (Clements Bartollas, 1990); dan kedua aspek tersebut pada hakekatnya telah menjadi landasan filosofi sistem peradilan pidana anak melalui ketentuan pasal-pasal yang terdapat dalam UU No. 3 Tahun 1997.

Ketentuan berkaitan dengan penanganan terhadap anak nakal berdasarkan UU No. 3 Tahun 1997 dapat dilihat dari jenis sanksi yang diberikan terhadap anak nakal. Sanksi terhadap anak nakal meliputi sanksi pidana dan tindakan. Sanksi pidana berupa pidana penjara, pidana kurungan, pidana denda atau pidana pengawasan (Pasal 23 ayat 2), pidana tambahan yang dapat berupa perampasan dan pembayaran ganti kerugian. Sedangkan tindakan yang dijatuhkan kepada anak nakal meliputi (1) dikembalikannya anak kepada orangtua/wali/orangtua asuh, hal ini dilakukan apabila hakim memandang bahwa si anak masih dapat dibina di lingkungan orangtua/wali/ orangtua asuh, namun si anak tersebut masih tetap di bawah pengawasan dan bimbingan Pembimbing Kemasyarakatan, (2) diserahkan kepada negara, hal ini dilakukan dalam hal hakim menilai bahwa pendidikan dan pembinaan terhadap anak nakal tidak dapat dilakukan di lingkungan keluarga, sehingga si anak ditempatkan di Lembaga Pemasyarakatan Anak (LPA) dan wajib mengikuti pendidikan, pembinaan dan Latihan Kerja, (3) diserahkan kepada Departemen Sosial atau Organisasi Sosial Kemasyarakatan.

Dalam perspektif kriminologi banyak teori atau konsep yang dikemukakan dalam rangka mencari solusi upaya menanggulangi kenakalan anak. Pola-pola prevensi, represif, dan kuratif seharusnya diterapkan secara tepat sehingga dapat mencapai hasil yang maksimal.

Dalam bukunya yang berjudul Principle of Criminology, Sutherland mengemukakan 2 metode untuk pencegahan kejahatan dalam arti luas, yaitu: Pertama, Metode prevensi yang meliputi berbagai usaha: a. Program prevensi umum; b. Organisasiorganisasi masyarakat; c. Kegiatan rekreasi; d. case work pada near-delinquent; e. group work dengan para near-delinquent; f. koordinasi badan-badan; 
g. lembaga-lembaga reorganisasi. Kedua, Metode reformasi, ditujukan untuk perbaikan penjahat, meliputi: a. Reformasi dinamik; b. Reformasi klinik; c. Reformasi hubungan kelompok; d. Professional service.

Semakin marak dan kompleksnya sebab-sebab (kausalitas) terjadinya kenakalan anak membawa konsekuensi yang berat pula dalam menentukan langkah-langkah yang konkrit (nyata) dalam rangka mencari cara yang tepat dan cepat upaya untuk menanggulanginya. Hukuman yang berat dan kesiapan aparat penegak hukum belum atau tidak dapat menjamin keberhasilan menanggulangi kenakalan anak, jika tidak dibarengi dengan partisipasi semua pihak, terutama pihak-pihak yang terkait erat dengan kegiatan anak khususnya kalangan anak sendiri. Untuk itu, selain perlu ditanamkan pendidikan dan disiplin yang baik, perlu pula diadakan kegiatan-kegiatan yang menunjang sportivitas dan solidaritas sosial di kalangan anak.

Dalam hal ini Paulus Hadisuprapto (2008:45) menyatakan bahwa berbicara tentang upaya penanggulangan kejahatan pada umumnya dan perilaku delikuensi anak pada khususnya dalam hukum pidana dikenal apa yang disebut Kebijakan Kriminal - usaha rasional masyarakat untuk menanggulangi kejahatan (termasuk perilaku delinkuenasi anak). Kebijakan kriminal dalam gerak langkahnya dapat dilakukan lewat sarana penal dan sarana non penal. Kedua kebijakan tersebut (penal dan non penal) merupakan pasangan yang saling menunjang dalam gerak langkah penanggulangan kejahatan pada umumnya dan perilaku delinkuensi anak pada khususnya di masyarakat. Selanjutnya disebutkan bahwa istilah delikuensi anak di dalamnya terkandung pengertian tentang criminal offence dan status offence. Perluasan makna perilaku delinkuensi anak tersebut di atas, sekaligus memberikan karakteristik dari pembicaraan tentang perilaku delinkuensi anak, yaitu bahwa pengertian delinkuensi anak lebih luas daripada pengertian kejahatan orang dewasa. Pengertian criminal offence dan status offence diakomodir oleh UU No. 3 Tahun 1997 tentang Pengadilan Anak, dimana dalam Pasal 1 huruf ke 2 dinyatakan bahwa anak nakal adalah (a) anak yang melakukan tindak pidana - criminal offence dan (b) anak yang melakukan perbuatan yang dinyatakan terlarang bagi anak, baik menurut peraturan perundang-undangan maupun menurut peraturan hukum lain yang hidup dan berlaku dalam masyarakat.

Selain itu, upaya penangulangan kenakalan anak secara yuridis harus memperhatikan masalah batasan usia anak nakal tersebut yang dapat bertanggungjawab, serta jenis atau bentuk pemidanaan apa yang paling tepat bagi si anak delinquent (sanksi pidana atau tindakan). Proses pengadilan anak (sebagai bentuk upaya penanggulangan yang bersifat represif) seharusnya dilaksanakan dalam rangka menyadarkan anak akan kesalahan yang diperbuatnya. Jangan sampai dalam proses tersebut menyebabkan "trauma" dikemudian hari yang dapat membahayakan tumbuh kembangnya anak tersebut.

Oleh karena itu, di samping Undang-Undang No. 3 Tahun 1997, para penegak hukum dan pihakpihak lain yang terkait dalam proses peradilan anak delinkuen seharusnya juga memperhatikan ketentuan yang terkait dengan masalah perlindungan anak (delinkuen) yang terdapat dalam Undang-Undang No. 23 Tahun 2002. Dengan memperhatikan aspekaspek health dan wealth si anak (Clemens Bartollas, 1990) diharapkan dapat tercipta suatu peradilan yang berkarakter restorative justice, dan jika dimungkinkan dapat dipilih suatu upaya di luar pengadilan (program diversi). Untuk itulah dibutuhkan partisipasi para ahli, khususnya ahli pendidikan, psikolog, psikiater, dan dokter mulai pada tahap anak ditangkap sampai di Lembaga Pemasyarakatan Anak supaya hak-hak anak delinkuen terlindungi. Pemilihan cara penanganan kasus kenakalan anak secara tepat sesungguhnya dapat berdampak positif bagi si anak supaya tidak berkembang menjadi residivis atau kriminal. Untuk itulah dana dan sarana pembinaan anak nakal di Lembaga Pemasyarakatana, misalnya, juga harus diperhatikan sebagai salah satu faktor yang mendukung upaya penanggulangan kenakalan anak secara represif (Sarwirini, 2002).

\section{PENUTUP \\ Kesimpulan}

Kausalitas dari timbulnya kenakalan anak dan upaya penanggulangannya dapat ditinjau, baik dari perspektif yuridis maupun non yuridis (khususnya kriminologi). Jika kedua perspektif tersebut digunakan secara tepat sesungguhnya akan menunjang Sistem Peradilan Anak yang bertujuan untuk perbaikan dan pertumbuhan fisik dan psikis yang baik, yang berguna bagi perkembangan pribadi dan sosial anak di kemudian hari. Untuk itulah para pihak yang terkait (khususnya aparat penegak hukum) harus melaksanakan penegakan hukum pidana anak yang berlandaskan pada Undang-Undang No. 3 Tahun 1997 tentang Pengadilan Anak dan Undang-Undang No. 23 Tahun 2002 tentang Perlindungan Anak secara konsisten dan konsekuen. 


\section{Rekomendasi}

Aspek health dan wealth perlu diperhatikan dalam upaya penanggulangan kenakalan anak yang bertujuan "untuk kepentingan yang terbaik bagi anak". Oleh karena ketidakadilan dalam proses peradilan anak delinkuen justru dapat memicu munculnya kenakalan anak dalam bentuk secondary deviant yang dalam aspek kualitas biasanya berkembang dalam bentuk yang lebih jahat. Untuk itulah upaya penanggulangannya secara preventif (pencegahan) maupun represif harus dilaksanakan secara sinergi dan terpadu dengan melibatkan pihak-pihak terkait.

\section{DAFTAR PUSTAKA}

\section{Buku:}

Bartolass, Clemens, 1990, Juvenile Deliquency, California: Macmillan Publishing Company.

Cloward, Richard A. dan Lloyn Ohlin, 1960, Delinquency and Opportunity: A Theory of Delinquent Gang, New York.

Cunneen, Rob White Chris, 2009, Juvenile Justice: Youth and Crime in Australia, Oxford: Oxford University Press.

Cohen, Albert K., 1955, Delinquent Boys, The Cultur of The Gang, New York.

Hadisuprapto, Paulus, 2008, Delikuensi Anak: Pemahaman dan Penanggulangannya, Malang: Bayumedia.

, "Pemberian Malu Reintegratif sebagai Sarana Nonpenal Penanggulangan Perilaku Delinkuensi Anak (Studi Kasus di Semarang dan Surakarta)", Disertasi, Program Doktor Ilmu Hukum Universitas Diponegoro, Semarang, 2002.

Hirschi, Travis, 1969, Causes of Delinquency, Berkeley.
Kartini, Kartono, 1986, Psikologi Sosial 2, Kenakalan Remaja, Jakarta: Rajawali.

Kaufman, James M., 1989, Characteristics of Behaviour Disorders of Children and Youth, Toronto: Merril Publishing Company Columbus London.

Lundman, J. Richard, 1993, Prevention and Control of Juvenile Deliquency, Oxford: Oxford University Press.

Mulyadi, Lilik, 2005, Pengadilan Anak di Indonesia: Teori Praktik dan Permasalahannya, Bandung: Mandar Maju.

Prinst, Darwan, 2003, Hukum Anak Indonesia, Bandung: Citra Aditya Bakti.

Saraswati, Rika, 2009, Hukum Perlindungan Anak di Indonesia, Bandung: Citra Aditya Bakti.

Sarwirini, "Viktimisasi Anak Delinkuen: Studi di Lembaga Pemasyarakatan Anak di Blitar, Laporan Penelitian, Surabaya: Lembaga Perlindungan Anak Jawa Timur, 2001-2002.

, "Kekerasan terhadap Murid dalam Kasus Bullying", Yustika - Media Hukum dan Keadilan, Vol. 12, No. 2, Universitas Surabaya, Surabaya, 2009.

, "Kekerasan di Dunia Pendidikan", Makalah

Pengabdian Masyarakat untuk Guru-Guru SMU dan SMK dalam Wilayah Diknas Pemerintah Kota Surabaya, Surabaya, 2010.

Soetodjo, Wagiati, 2008, Hukum Pidana Anak, Bandung: Refika Aditama.

Taylor, Lamar and Mark C. Stafford, 1995, American Deliquency, California: Wadsmorth Publishing Company. 